\title{
Ortaokul Türkçe Ders Kitaplarında Kelime Öğretimi Üzerine Öğretmen Görüşlerinin Değerlendirilmesi*
}

\author{
Ali Göçer**, Bekir Sıddık Kılıç***
}

Makale Geliş Tarihi: 07/01/2020

Makale Kabul Tarihi: 30/11/2020

DOI: $10.35675 /$ befdergi.671707

$\ddot{O} z$

Bu çalışmada ortaokul Türkçe ders kitaplarında kelime öğretimine ilişkin öğretmen görüşlerinin alınması amaçlanmıştır. Araştırma Millî Ĕ̆itim Bakanlığına bağlı ortaokullarda görev yapan on beş ögrretmen ile yürütülmüştür. Nitel yöntemle yapılan çalışmanın verileri araştırmacılar tarafindan hazırlanan yarl-yapılandırılmış görüşme formu ile elde edilmiştir. Hazırlanan görüşme formu iki ögretim üyesinden uzman görüşü alınarak düzenlenmiştir. Öğretmenlerden elde edilen görüşme formu üzerinde kodlamalar yapılarak söz konusu veriler içerik analizine tabi tutulmuştur. Öğretmenlerden alınan görüşler çerçevesinde ortaokul Türkçe ders kitaplarında kelime ögretimi etkinliklerinin programla uyumu, etkinliklerin yeterli olma durumu, kelime ögretimine ayrllan süre, kelime öğretiminde karşılaşılan sorunlar ortaya konmuştur. Sonuç olarak Türkçe öğretmenlerinin kelime öğretiminde farklı yöntemler ve süreler kullandıkları, kılavuz kitaplarının kaldırılmasını kelime öğretimi açısından olumsuz buldukları tespit edilmiştir.

Anahtar Kelimeler: Ders kitabl, dil yeterliği, kelime öğretimi, Türkçe eğitimi

\section{Evaluation of Teachers' Views on Teaching Vocabulary in Secondary School Turkish Coursebooks}

\begin{abstract}
In this study, it was aimed to get the opinions of teachers about teaching vocabulary in secondary school Turkish coursebooks. The research was carried out with fifteen teachers working in secondary schools affiliated to the Ministry of National Education. The data of the study conducted with the qualitative method were obtained using a semi-structured interview form prepared by the researchers. The interview form was prepared by taking expert opinion from two faculty members. The content analysis of the data was made by coding on the interview
\end{abstract}

* 21-24 Mart 2019 tarihinde Uluslararası Bilim ve Eğitim Kongresinde sunulan bildirinin genişletilmiş hâlidir.

** Erciyes Üniversitesi, Eğitim Fakültesi, Türkçe ve Sosyal Bilimler Eğitimi Bölümü, Türkçe Eğitimi Anabilim Dalı, Kayseri, Türkiye, gocerali@gmail.com, ORCID: 0000-0002-68802611

*** Kilis 7 Aralık Üniversitesi, Muallim Rıfat Eğitim Fakültesi, Türkçe ve Sosyal Bilimler Eğitimi Bölümü, Türkçe Eğitimi Anabilim Dalı, Kilis, Türkiye, bskilic@kilis.edu.tr, ORCID: 0000-0003-3959-1867

Kaynak Gösterme: Göçer, A. \& Kılıç, B. S. (2021). Ortaokul Türkçe ders kitaplarında kelime öğretimi üzerine öğretmen görüşlerinin değerlendirilmesi. Bayburt Ĕ̆itim Fakültesi Dergisi, 16(31), 1-20. https://doi.org/10.35675/befdergi.671707. 
form obtained from the teachers. By getting the opinions from the teachers, the compatibility of the vocabulary teaching activities with the curriculum in the secondary school Turkish coursebooks, the sufficiency of the activities, the time allocated for teaching vocabulary, and the problems encountered in teaching vocabulary were revealed. As a result, it was found that Turkish teachers used different methods and durations in vocabulary teaching, and they thought that the removal of guidebooks had a negative effect on vocabulary teaching.

Keywords: Coursebook, language proficiency, Turkish education, vocabulary teaching

\section{Giriș}

Dilin konuşurlarının düşünüş tarzları, hayat felsefeleri, olaylar karşısındaki tavırları dile yansır, dil de insanları şekillendirir çünkü insan, kelimeleriyle düşünür (Akar, 2019). Ergin'e (1986, s. 95) göre sözcük, anlamı ya da gramer vazifesi bulunan ve tek başına kullanılan ses veya sesler topluluğudur. Kelimeler günlük yaşamda, ilişki ve iletişimde, duygu, düşünce ve isteklerimizi anlatmada önemli önemli bir fonksiyonu yerine getirir. "Hayaller ve duygular kısmen; düşünceler tamamen kelimelere dayanır” (Baskın, İşcan, Karagöz \& Birol, 2017). Sosyal bir varlık olan insan, dilin önemli unsurlarından kelimeler sayesinde anlama ve anlatma becerilerini geliştirir. "Konuşurken ya da yazarken seçtiğimiz kelimelerle düşüncelerimizi dolayısıyla kendimizi ifade ederiz" (Baş \& Demirci, 2015, s. 18). İletişimin asıl ögelerinden mesajın, kaynak tarafından olması gerektiği gibi kodlanıp alıcı tarafından da anlaşılabilmesi, tarafların söz varlığı ile ilgilidir (Yılmaz \& Doğan 2014, s. 281). "Dil bilim çalışmalarında, dilin kelimeleri, terimleri, yabancı dillerden alınan unsurları, atasözleri, deyimleri, kalıp sözleri bir bütün olarak sözvarlığı adı altında ele alınmaktadır" (Aksan, 2014, s. 13). Kişinin sahip olduğu zengin kelime bilgisi onu toplumda ayrı bir konuma oturtmakta, olaylara ve durumlara bakış açısını etkilemektedir. "İletişimin birincil hedeflerinden biri olarak rol üstlenen kelime bilgisi, insanların düşünme, anlama, öğrenme ve zihinsel becerilerini geliştirmekte ve başarılarını artırmaktadır" (Güneş, 2013; Nation \& Newton, 1997). Ulusal ve uluslararası sınavlarda kelime bilgisinin, anlama ve yorumlama becerilerini artırdığ bu durumun da başarıyı etkilediği bilinmektedir. "Eğitimciler kelime dağarcığı ile akademik başarı arasındaki ilişkiyi kabul etmekte, kelime dağarcı̆̆ı çalışmalarını anadil eğitiminin önemli bir parçası olarak görmekte çünkü kelime bilgisindeki yetersizliğin akademik başarıyı sınırladığını düşünmektedirler” (Özaslan, 2006, s. 35). Sözcük öğretimi tüm dersler kapsamında gerçekleştiriliyor olsa da bu alanda en büyük sorumluluk ana dil öğretiminin gerçekleştirildiği derslere düşmektedir (Anılan \& Genç, 2011, s. 113). Söz varlığının geliştirilmesinde Türkçe dersleri ve bu derslerde yapılan faaliyetler ön plana çıkmaktadır. "Öğrencilerin dil yeterliklerini geliştirme amacıyla öğrenme ve öğretme sürecinde gerçekleştirilecek en önemli çalışmalar arasında sözcük öğretimi etkinlikleri gelmektedir” (Göçer, 2018, s. 295). Türkçe programlarının asıl amaçlarından biri söz varlığının zenginleştirmektir; çünkü dil hem bilişsel gelişimde bir gösterge hem de yaşanan topluma uyum sağlamada önemli bir vasıtadır (Mert, 2013, s. 15). Bireylerin sözcük dağarcığının geliştirilmesine Türkçe 
eğitimi uygulamalarında ağırlık verilmekte, okullarda özellikle metin işleme süreçlerinde söz varlığını geliştirme etkinliklerini amaçlı ve planlı yapmak gerekmektedir (Göçer, 2015, s. 18).

Millî Eğitim Bakanlığı (MEB), Türkçe Dersi Öğretim Programı Ortaokul 5, 6, 7 ve 8. Sınıflar için kelime öğretiminde kazanımlardan bazıları şunlardır (MEB, 2018, s. 21-51):

Dinlediklerinde/izlediklerinde geçen, bilmediği kelimelerin anlamını tahmin eder (T.5.1.2), Dinlediklerinde/izlediklerinde geçen, bilmediği kelimelerin anlamını tahmin eder (T.6.1.2), Dinlediklerinde/izlediklerinde geçen, bilmediği kelimelerin anlamını tahmin eder (T.7.1.2), Dinlediklerinde/izlediklerinde geçen bilmediği kelimelerin anlamını tahmin eder (T.8.1.2).

Sözcük öğretiminin gerçekleştirmesinde yararlanılan kaynakların başında ders kitapları gelmektedir. Ders kitaplarında yer alan etkinlikler, etkinliklerin uygulanma yöntem ve teknikleri kelime öğretimi süreçlerinin önemli unsurları arasında yer almaktadır. "Anadili öğretimi sürecinde ders kitapları, Türkçe dersinin amaçları ile öğrenme alanları ve sınıflara göre kazanımların gerçekleştirilmesinde büyük bir görev üstlenmekte, ders içerikleriyle ilgili bilgileri pekiştirme, sınavlara hazırlama ve öğrencilerin öğrenme hızlarına uygun çalışma olanağı sunmaktadır" (Güzel, 2015, s. 27; Mert, 2013, s. 7). Ders kitaplarında edinilen birikimlerin günlük yaşam becerilerine aktarılması gerekmektedir. "Ders ve çalışma kitapları öğrencilerin edindikleri bilgileri günlük hayata ve uygulamaya aktarmada kılavuzluk ettiğinden bu işlevinin ihmal edilemeyeceği düşünülmektedir” (Bay, 2014; Göçer, 2007).

2015 yılında değiş̧en Türkçe ders programıyla beraber ders kitapları setler şeklinde dağıtılmıştır (Alkış Küçükaydın \& İşcan, 2017, s. 2-3). Öğretmen kılavuz kitaplarında birçok bakımından öğretmenler için yol gösterici etkinlikler, yönergeler bulunmaktadır. Eğitimde çok sık kullanılan materyaller arasında olması sebebiyle Türkçe ders kitaplarıyla ilgili birçok çalışma yapılmıştır (Açıkgöz, 2008; Arı, 2003; Baysal, 2007; Çiftçi \& Çeçen, 2010; Demir, 2010; Mert, 2010).

Kelime hazinesi edindirmede Türkçe ders kitaplarını inceleyen Kurudayığlu ve Karadağ (2006) öğrencilerin yüksek yaygınlık ve sıklıkta kullandıkları kelimeler ile onlar için hazırlanan kitaplardaki metinler arasında uyum olmadığını tespit etmiş̧ir. İlköğretim Türkçe ders kitaplarındaki sözvarlığını incelediği çalışmasında Kaya (2008), bazı kitaplarda sözcük çalışması bulunmadı̆̆ını, toplam etkinlikler arasında sözcük çalışmaları oranının verimli bir sözcük öğretimi için eksik olduğunu saptamış, kitaplardaki metinlerin değiştirilmesi ve seviye düzenlemelerinin yapılması gerektiğini ifade etmiştir. Altıncı sınıf Türkçe dersi sözcük öğretimi etkinliklerini çeşitli değişkenler açısından ele alan Gündoğdu (2012) çalışma kitaplarında sözcük öğretimiyle ilgili etkinliklerde en sık kullanılan yöntemlerin bağlam, aktarma ve tanımlama olduğunu tespit etmiş̧ir. Aru Akyüz (2013) Türkçe öğretim programı çerçevesinde hazırlanan kitaplarda öğrencilere kazandırılması gereken kelimelerin 
öğretiminin nasıl yapıldığını ele aldığı çalışmada; hiçbir metinde anahtar kavramın ayırt edilebilecek biçimde düzenlenmediğini, metinlerin söz varlığını geliştirmeye yönelik hazırlanmadığını ve kelime öğretiminin planlı yapılmadığını tespit etmiştir. Türkçe programıyla çalışma kitaplarındaki kazanım ve etkinlikleri sözcük öğretimi bağlamında ele alan Mert (2013) çalışma kitaplarında Türkçe öğretimi programında yer alan kazanımların tamamını örnekleyen etkinliklerin bulunmadığını, kitaplardaki sözcük öğretimine yönelik etkinliklerin yeterli olmadığını, programda söz varlığını zenginleştirme amacına yönelik oluşturulan kazanımlar ve etkinlik örneklerinin uyumlu olduğunu tespit etmiştir. Güzel (2015) Türkçe ders kitaplarında sözcük öğretimini, yaratıcı dil öğretimi açısından ele almış, söz figürü etkinliklerinin temel anlamlı sözcük öğretimi etkinliklerine göre fazla olduğunu, yaratıcı dil kullanımını geliştirme açısından yalnızca niceliksel olarak yeterli olduğunu tespit etmiştir. Öğretmen kılavuz kitaplarında sözcük öğretimiyle ilgili yer alan açıklama ve yönergelerin öğrenci çalışma kitaplarında tam olarak uygulanamadığı, ortaokul Türkçe dersi öğrenci çalışma kitaplarındaki temel anlamlı sözcük öğretimi etkinliklerinin de mekanik, tekrarcı ve durağan olduğu aynı çalışmanın sonuçlarındandır. Baş ve Demirci (2015) Türkçe ders ve çalışma kitaplarındaki etkinlikleri kelime varlığı açısından karşılaştırmıştır. Ders ve çalışma kitaplarında yer alan ortak kelime oranının ve çalışma kitabında bilinmeyen kelimelerin sıklık oranının düşük olduğunu, programda yer alan söz varlığını geliştirme amacının ihmal edildiğini tespit etmiştir. Türkçe ders kitaplarıyla ilgili birçok çalışmanın yapıldığı, yapılan çalışmaların kelime sıklık, kelime öğretim yöntem ve teknikleri, ders ve çalışma kitapları arasındaki uyum gibi konular etrafında toplandığı görülür. 2018 2019 eğitim-öğretim döneminde yapılan değişiklik ile öğretmen kılavuz kitapları kaldırılmış, Türkçe ders kitapları ile öğrenci çalışma kitapları birleştirilmiştir. Çalışmada "Türkçe ders ve çalışma kitaplarının birleştirilmesi, öğretmen kılavuz kitaplarının kaldırılması, kelime öğretimini nasıl etkilemiştir?” sorusuna odaklanılmıştır. Türkçe çalışma kitaplarının ders kitaplarıyla birleştirilmesinin, öğretmen kılavuz kitaplarının kaldırılmasının, kelime öğretimi üzerine etkisini öğretmen bakış açısıyla ele alan çalışmaların sınırlı olması çalışmanın yürütülmesinde etkili olmuştur. Çalışmanın alan yazına katkı yapması beklenmektedir.

\section{Yöntem}

\section{Araştırmanın Modeli}

Çalışmada nitel araştırma yöntemlerinden durum çalışması deseni tercih edilmiştir. Nitel araştırma gözlem, görüşme ve doküman analizi gibi veri toplama yöntemlerini kullanarak olgu ve olayları gerçekçi ve bütüncül bir biçimde ortaya koyan bir araştırma türüdür (Yıldırım \& Şimşek, 2016). Nitel durum çalışmalarının asıl özelliği bir duruma ilişkin etkenler, bütüncül bir yaklaşımla araştırılır ve ilgili durumdan nasıl etkilendikleri üzerine odaklanılmasıdır (Yıldırım \& Şimşek, 2016). Ortaokul Türkçe ders kitaplarında öğretmen kılavuz kitaplarının kaldırılması, ders ve çalışma 
kitaplarının birleştirilmesi durumlarının kelime öğretimi üzerindeki etkisinin öğretmen görüşleri çerçevesinde incelemek amacıyla durum çalışması deseni tercih edilmiştir.

\section{Çalışma Grubu}

Araştırmanın katılımcıları amaçlı örnekleme türlerinden kolay ulaşılabilir durum örneklemesine göre seçilmiştir. Kolay ulaşılabilen örneklemler daha az maliyetlidir ayrıca bilinen, tanınan bir örneklem üzerinde çalışma, bazı araştırmacılar için daha pratik ve kolay algılanabilir (Yıldırım \& Şimşek, 2016). Çalışma sürecinde pratiklik sağlamak adına araştırmacılar, çalışma grubunu etkileşim içerisinde olduğu Türkçe öğretmenlerinden seçerek kolay ulaşılabilir durum örneklemesini tercih etmiştir. On beş kişiden oluşan çalışma grubunun hepsi Türkçe öğretmenidir. Çalışmada katılımc1 isimlerine yer verilmemiş, öğretmenler, Ö1, Ö2, Ö3, Ö4... şeklinde kodlanmıştır. Katılımc1lara ait bilgiler Tablo 1'de yer almaktadır:

Tablo 1.

Çalışma Grubunun Özellikleri

\begin{tabular}{lll}
\hline & Cinsiyet & Mesleki Deneyim \\
\hline Ö1 & Erkek & $1-5$ y1l \\
Ö2 & Erkek & $1-5$ y1l \\
Ö3 & Kadın & $1-5$ y1l \\
Ö4 & Kadın & $1-5$ y1l \\
Ö5 & Kadın & $1-5$ y1l \\
Ö6 & Erkek & $1-5$ y1l \\
Ö7 & Kadın & $1-5$ y1l \\
Ö8 & Erkek & $5-10$ y1l \\
Ö9 & Kadın & $5-10$ y1l \\
Ö10 & Erkek & $5-10$ y1l \\
Ö11 & Erkek & $5-10$ y1l \\
Ö12 & Kadın & $5-10$ y1l \\
Ö13 & Kadın & $5-10$ y1l \\
Ö14 & Erkek & 10 y1ldan fazla \\
Ö15 & Kadın & 10 y1ldan fazla \\
\hline
\end{tabular}

Türkçe öğretmenlerinin sekizinin kadın yedisinin erkekten oluştuğu, mesleki deneyimlerin 7 öğretmenin 1-5 yılları arasında, 6 öğretmenin 5-10 yılları arasında ve 2 öğretmenin de 10 yıldan fazla olduğu görülmektedir.

\section{Veri Toplama Süreci ve Aracı}

Araştırmada veri toplama aracı olarak görüşme kullanılmıştır. Doğrudan gözleme imkânı olamayan bilgilere ulaşma olanağı sağlayan görüşme ayrıca dıştan görülen 
eylemlere içsel bir bakış açısı da sağlayabilmektedir (Anagün, 2008, s. 90). Türkçe öğretmenlerinin, kelime öğretimiyle ilgili düşüncelerini ele almak amacıyla yarı yapılandırılmış görüşme kullanılmıştır. Formun hazırlanmasından önce alan yazın incelenmiş, açık uçlu on soruluk görüşme formu hazırlanmıştır. Soruların öğretmenler tarafından yeterince anlaşılma durumunu test etmek için pilot uygulama yapılmıştır. Gönüllülük esasına bağlı olarak öğretmenlerle ortalama 30 dakika süren görüşmeler yapılarak görüşmeler bilgisayara kaydedilmiştir.

\section{Verilerin Analizi}

Farklı zamanlarda okunan yazılı metinler üzerinde çalışmanın görüşme soruları çerçevesinde kod, kategori ve temalar oluşturulmuştur. Elde edilen ham veriler başlıklara ayrılmadan analiz edildiğinden verilerin analizinde içerik analizi kullanılmıştır.

Kodlama güvenirliği hesaplanırken Miles ve Huberman’ın (1994) “Görüş birliği/ (Görüş birliği + Görüş ayrılığı) x 100” formülü kullanılmış, araştırmacılar arasındaki güvenirlik ,81 bulunmuştur. Bulgular, tablolar hâlinde sunulmuş, bazı katılımcı ifadelerine yer verilmiştir.

\section{Geçerlik ve Güvenirlik}

Çalışmanın geçerlik ve güvenirliğini sağlamak adına araştırmacılarca bazı önlemler alınmıştır. Çalışmanın iç geçerliliğini sağlamak için görüşme formunun düzenlenmesinde bir alan uzmanının görüşüne başvurulmuştur. Öğretmenlerle gerçekleştirilen görüşmeler sonucunda öğretmenlerin yanıtlarını onaylamaları istenmiş, gerekli kısımlarda düzeltmeler yapılmıştır.

Çalışmada dış geçerliği sağlamak amacıyla çalışmanın modeli, çalışma grubu, veri toplama araçları, verilerin toplanması ve analizi hakkında bilgi verilmiştir. Çalışma grubunu oluşturan öğretmenlerin farklı kıdem, yaş ve cinsiyet gruplarından oluşması sebebiyle çalışmanın uygun katılımcılardan oluştuğu düşünülmektedir. Çalışmanın 15 kişiyle sınırlı tutulması dış geçerliği sınırlayan bir durum olarak düşünülebilir. Verilerin araştırmacılarca farklı zamanlarda okunup ortak kodların oluşturulması, güvenirliği arttırmak amacıyla gerçekleştirilmiştir.

Makalenin yazarı olarak, bu makalede bilimsel ve etik kurallara uyulduğunu beyan ederim.

\section{Bulgular ve Yorum}

Türkçe öğretmenlerinin görüşlerinden hareketle oluşturulan araştırma bulgularına aşağıda yer verilmiştir.

Türkçe öğretmenlerinin eğitim aldıkları bölümde kelime öğretimi konusunda akademik olarak bilgilendirilme durumlarıyla ilgili görüşleri alınmış ve buna ilişkin görüşler Tablo 2'de gösterilmiştir: 
Tablo 2.

Kelime Öğretimi Konusunda Bilgi Alma Durumlarına İlişkin Bulgular

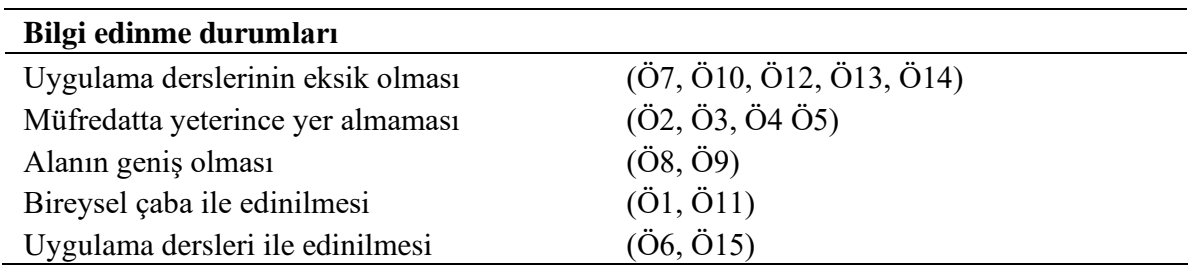

Tablo 2'den hareketle öğretmenlerin büyük çoğunluğu bu konuda yetersiz bilgilendirildiklerini ifade ederken yalnız dört öğretmen yeterince bilgi edindiklerini, ifade etmişlerdir. Kelime öğretimiyle ilgili yeterince akademik bilgi edinmediğini belirten öğretmenlerden Ö7, düşüncesini şu şekilde ifade etmiştir: “Lisans ĕgitimim sırasında aldı̆̆ım derslerde kelime ögretimiyle ilgili yeterli bilgi edindiğimi düşünmüyorum çünkü derslerimizde yeterince üzerinde durulan bir konu değildi. Son sınıfta yaptı̆̆ım staj çalışmalarımda da kelime öğretimi ile ilgili mesleki yeterlilik kazandığımı düşünmüyorum. Kelime öğretiminin nasıl yapılacă̆ını lisans öğrenimim değil daha çok çalışma hayatımdaki tecrübelerim belirlemiştir.” Aynı görüşte olan Ö6 da lisans derslerinin edebiyat ve dil bilgisi ă̆ırlıkl olduğundan özel ögretim yöntemleri ve öğretmenlik uygulaması dersi dışında bu konuda çalışma yapılmadı̆̆ını dile getirmiştir. Kelime öğretimi konusunda yeterince bilgilendirildiğini Ö1, " $\ddot{O ̈}_{z e l}$ ögretim yöntemleri dersinde bu konuda çok uygulama yapmıştık, şimdi de derslerimde ögrrendiklerimi kullanıyorum. Faydalı olduğunu da düşünüyorum.” şeklinde açıklamaktadır.

Tablo 3.

Kılavuz Kitapların Kaldırılmasının Kelime Öğretimini Etkileme Durumuna İlişkin Bulgular

\begin{tabular}{|c|c|}
\hline \multicolumn{2}{|c|}{ Kılavuz kitapların kaldırılmasının etkisi } \\
\hline Metin seçiminin önemli olması & (Ö3, Ö6, Ö13) \\
\hline Öğretmeni daha aktif kılması & (Ö1, Ö2, Ö9) \\
\hline Başvuru kaynağı olması & (Ö4, Ö5) \\
\hline Farklı kaynaklara yönlendirmesi & (Ö10, Ö15) \\
\hline Mesleki tecrübeye göre değişmesi & (Ö8, Ö11) \\
\hline Öğretmeni hazıra alıştırması & (Ö14) \\
\hline Yanlış öğrenmelere neden olması & (Ö12) \\
\hline Yol gösterici olması & (Ö7) \\
\hline
\end{tabular}

Tablo 3'te kılavuz kitapların kaldırılmasının kelime öğretimini etkileme durumlarına ilişkin veriler yer almaktadır. Tablo 3 'ten Türkçe öğretmenlerinin beşinin bu uygulamayı olumsuz, beşinin olumlu karşıladığı görülmektedir. Kılavuz kitapların kaldırılmasının kelime öğretimini herhangi bir şekilde etkilemediğini düşünen üç öğretmen; durumun öğretmen tecrübesine bağlı olduğunu düşünen iki öğretmen 
bulunmaktadır. Kılavuz kitapların kaldırılmasını olumsuz karşılayan Ö7, "Kılavuz kitaplar öğretmenin ulaşabileceği en hızl ve en ekonomik ders materyallerinden biridir. Kılavuz kitaplarda bazen ders öncesi hazırlıkta ve ders esnasında aklımıza gelmeyen öğretim teknikleri yer almaktadır. Bazen fiziki ve teknik yetersizliklerden doğan olumsuzluklarla karşılaşmaktayız böyle durumlarda kelime öğretimi ile ilgili yardım alabileceğimiz ilk kaynă̆ın kılavuz kitaplar olduğunu düşünmekteyim." Aynı konuda farklı görüşte olan Ö1, düşüncesini “Kılavuz kitapların kaldırılması öğretmeni daha aktif hâle getiriyor, daha çok çalışmaya yönlendiriyor. Kılavuz kitaplar ögretmeni hazıra alıştırıyor." şeklinde dile getirmiştir. Kılavuz kitapların kaldırılmasının kelime öğretimini olumlu ya da olumsuz etkilemediği, önemli olanın kelime öğretimi için seçilecek metinlerin olduğunu Ö3, şöyle belirtmiştir: "Kılavuz kitapların kaldırllması kelime ögretimini çok etkilemiyor, kılavuz kitaplarından ziyade metinlerde yabancı dilden alınmış kelimeler bulunmakta, okuma metinleri doğru seçilmemektedir. Bazl metinlerde bizim bile anlamakta zorluk çektiğimiz kelimeler var." Yukarıda verilen düşüncelerin yanı sıra kılavuz kitapların etkisini mesleki tecrübeye bağlayan öğretmenler de bulunmaktadır. Bu şekilde düşünen öğretmenlere göre söz konusu kitapların kaldırılması mesleğin ilk yıllarındaki ögretmenleri olumsuz etkileyebilirken, tecrübeli öğretmen açısından problem olmamaktadır (Ö11).

Tablo 4.

Ders ve Çalışma Kitaplarının Birleştirilmesinin Kelime Öğretimini Etkileme Durumuna İlişkin Bulgular

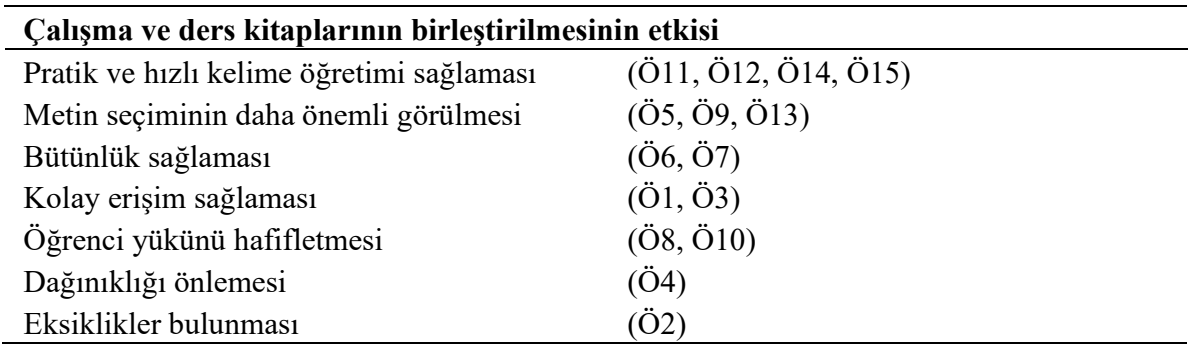

Tablo 4'te ders kitaplarıyla çalışma kitaplarının birleştirilmesinin kelime öğretimine etkilerine dair bilgiler bulunmaktadır. Tablo 4'e göre öğretmenlerin çoğunluğunun değişikliği olumlu bulduğu, bazılarının değişikliğin herhangi bir etkisinin olmadığını düşündüğü, bir öğretmenin de değişikliği olumsuz karşıladığı görülmektedir. Yapılan değişikliğin kelime öğretimini olumlu etkilediğini düşünen öğretmenlerden bazıları görüşlerini şu şekilde dile getirmektedir: Öğrenci kelimenin anlamını metnin bağlamından tahmin ettiği için iki kitap yerine tek kitapla ve hızlı olarak sonuca ulaşlyor (Ö6). Öğretmenin kelime öğrenme ile ilgili rehberlik ettiğ $i$ durumlarda kitabı derse getirmeyi unutan bir öğrenci zaten kelime öğrenmeyi ve ders iklimini olumsuz yönde etkilemektedir (Ö7). Söz konusu kitapların birleştirilmesinin kelime öğretimi üzerinde herhangi bir etkisinin olmadığını düşünen Ö5'e göre ders 
kitaplarındaki metinlerin ve etkinliklerin nitelikli olması durumunda kitapların birleştirilmesinin kelime öğretimine katkısı olmamaktadır. Görüşme esnasında Ö5'e nitelikli olarak neyi kastettiği sorulduğunda yabancı kelimeler yerine Türkçe kelimelerin kullanıldığ , edebî zevki yüksek eserlerden seçilen ve yazım, anlatım hatası olmayan metinler şeklinde açıklamada bulunmuştur. Ders ve çalışma kitaplarının birleştirilmesini kelime öğretimi açısından olumsuz olduğunu düşünen Ö2, kitapların birleştirilmesinde eksiklikler olduğu kanaatindeyim. Her ne kadar ögrencilerin yükünü hafifletmek için yapllan bir uygulama olsa da öğrencilerin kelime ve kavram dăgarcı̆̆ının gelişmesini ve zenginleşmesini olumsuz etkilemiştir.

Tablo 5.

Kelime Öğretimi Etkinliklerinin Türkçe Öğretim Programıla Uyumlu Olma Durumlarına İlişkin Bulgular

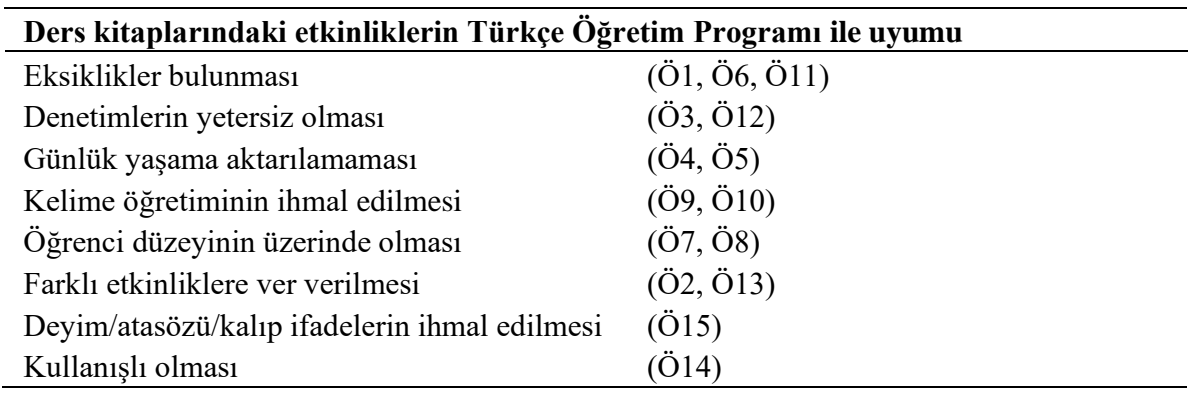

Tablo 5'te ders kitaplarında yer alan kelime öğretimi etkinliklerinin programla uyumuna dair veriler sıralanmıştır. Etkinliklerin, Türkçe Öğretimi Programı ile uyumlu olduğunu düşünen altı öğretmen, kısmen uyumlu olduğunu düşünen dört öğretmen, uyumsuz olduğunu düşünen üç öğretmen ve durumun, kitapların yayınevine göre değiştiğini düşünen iki öğretmen bulunmaktadır. Kelime öğretimi etkinliklerinin Türkçe Öğretim Programına uygun hazırlandığını dile getiren Ö9'a göre ögretim programında yer alan kazanımlar doğrultusunda ögrencilere birçok seçenek sunulmuştur. Öğrencilerin zevkle yaptığı etkinlikler arasında bulmaca, adam asmaca, tahmin etme, anahtar sözcükleri belirleme, sözcükleri anlamlar ile eşleştirme gibi çeşitli etkinlikler yer almaktadır. Etkinliklerin, programla kısmen uyuştuğu şeklinde düşünen Ö11, görüşünü şöyle ifade etmiştir: Etkinliklerin bazılarının uyumlu olmasına răgmen bazı etkinlikler ögrencilerin kapasitesinin üzerinde hazırlanmıştır. Etkinliklerle programın kısmen uyumlu olduğunu düşünen bir öğretmenle, uyumsuz olduğunu düşünen bir öğretmenin ögretim programı çoğu zaman havada kallyor yani yapılan etkinlikler, istenilenle uyuşmuyor bu açıdan etkinliklerin programla uyumsuz olduğunu düşünüyorum (Ö13) şeklindeki görüşünün benzer olduğu görülmektedir. Söz konusu uyumun yayınevine göre değiştiğini ifade eden öğretmenlere göre ise sınıf sınıf ve düzey düzey baktı̆̆ımızda bazı yayınevlerinden çıkan ders kitaplarının ve etkinliklerdeki gerekli incelemelerin çok da 
üst düzey biçimde yapılmadı ̆̆ , baştan savma kitaplar düzenlendiği, özellikle MEB yayınları haricindeki özel yayınların yetersiz kaldığı (Ö3, Ö12) görülmektedir.

Tablo 6.

Ders Kitaplarındaki Kelime Öğretimi Etkinliklerinin Yeterli Olma Durumuna İlişkin Bulgular

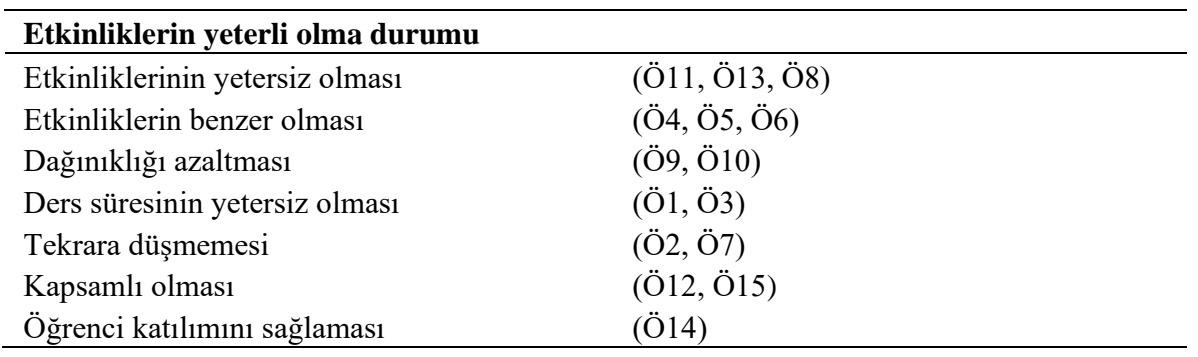

Tablo 6'da öğretmenlerin birleştirilen Türkçe kitaplarındaki kelime öğretimi etkinliklerinin durumlarına ilişkin görüşleri sıralanmaktadır. Tablo 6'ya göre kelime öğretimi etkinliklerini yeterli ve yetersiz olduğunu düşünen öğretmen sayılarının eşit olduğu görülmektedir. Aynı tablodan bazı öğretmenlerin etkinlikleri kısmen yeterli buldukları görülmektedir. Kitaplardaki kelime öğretimi etkinliklerini yeterli bulan Ö2'ye göre birleştirilmiş yeni Türkçe ders kitaplarındaki etkinlikler kelime öğretimi açısından yeterlidir. Bu etkinliklerle önemli olan kelimeleri sözlükteki anlamları ile öğrenmek yerine cümle içindeki anlamlarlyla öğretmek daha faydalı olacaktır. Yani mevcut etkinlikler yeterli onu daha yeterli hâle getirmek daha önemli diye düşünüyorum şeklindedir. Aynı konuda farklı görüşte olan Ö12 de görüşünü kelime ögretimi etkinliklerinde tüm metinlerde aynı etkinlikler kullanıllyor bunun için yetersiz buluyorum. Farkl etkinlikler ve anlama-anlatma alanlart üzerinde durulabilir şeklinde dile getirmiştir. Bahsi geçen etkinliklerin kısmen yeterli olduğu savını destekleyen öğretmenlerden Ö14'e göre daha eğlenceli, zamanı daha iyi geçirilebilecek etkinliklerin sayısı artırılmalıdır.

Tablo 7.

Öğretmenlerin Kelime Ö̆̆retimine Ayırdıkları Sürelere İlişkin Bulgular

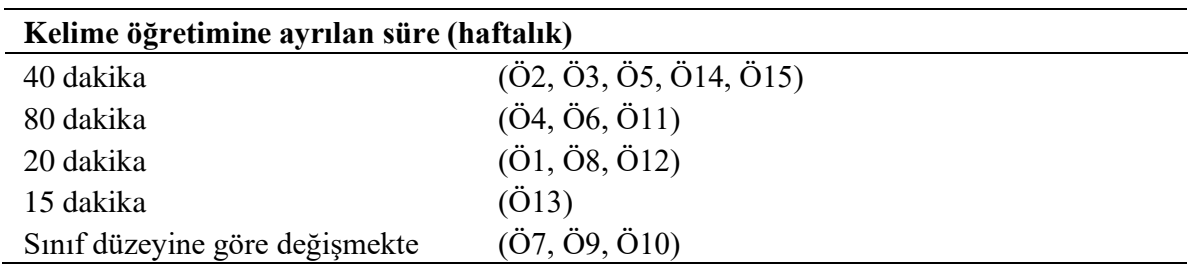

Öğretmenlerin kelime öğretimine ayırdıkları sürelere ilişkin veriler Tablo 7'de gösterilmiştir. Öğretmenlerinden bazıları haftalık bir ders saatini, bazıları 15, 20, 80 dakika gibi süreleri kelime öğretimine ayırmaktadır. Kelime öğretimine ayrılan 
sürenin sınıf düzeyine değiştiğini düşünen Ö9'a göre kelime ögretimi için 5. ve 6 . sinıflara haftalık 40 dakika, 7. ve 8. sinıflara ise 25 dakika yeterlidir.

Tablo 8.

Kelime Öğretimi için Kitaplardaki Etkinlikler Dışında Yapılan Uygulamalara İlişkin Bulgular

\begin{tabular}{ll}
\hline \multicolumn{2}{l}{ Kitap haricinde gerçekleştirilen uygulamalar/etkinlikler } \\
\hline Kelime oyunları & (Ö9, Ö6, Ö14, Ö15) \\
Kelime defteri tutma & (Ö3, Ö5, Ö13) \\
Kitap okuma & (Ö2, Ö12, Ö8) \\
Teknolojiden faydalanma & (Ö4, Ö11) \\
Yazma çalışmaları & (Ö1, Ö7) \\
Öğretim tekniği & (Ö12) \\
\hline
\end{tabular}

Tablo 8'de Türkçe öğretmenlerinin, kitaplardaki kelime öğretimi etkinlikleri dışında yapmış oldukları uygulamalara ilişsin veriler yer almaktadır. Tablo 8 incelendiğinde en çok kelime oyunlarının tercih edildiği, onu kitap okuma ve kelime defteri tutma faaliyetlerinin takip ettiği görülmektedir. Aynı tabloda sırayı öğrenilen yeni kelimelerle yazma çalışmaları ve akıllı tahta, yansı cihazı gibi teknolojik aletler kullanılması izlemekte, beyin fırtınası tekniğini kullanan öğretmenin olduğu da görülmektedir. Kitaptaki etkinlikler haricinde kelime öğretimi için kelime oyunlarını kullanan Ö2, kitaplardaki etkinlikler haricinde kelime avı etkinliği yapıyorum. Okuma metnindeki kelimelerden bazllarını tahtaya yapıştırıyorum. Sinıfı iki gruba ayırarak ellerine çubuk veriyorum, parçayı okutmaya başllyorum. Parçada geçen tahtada olan kelimeyi ilk gören ögrenci kelimenin üstüne çubukla vurup grubuna puan kazandırıyor. Bunun dışında hızlı kelime aktiviteleri de yaptırıyorum. Yeni öğrenilen kelimeleri bir deftere yazdırıp kelime defteri oluşturmasına yönelik uygulamalar yapan Ö5, kelimeleri yazarken varsa eş veya zıt anlamlarının yazılması ve yeni ögrenilen kelimelerin konuşulup yazılması bunların yanı sıra yeni öğrenilen deyimlerin ve kelimelerin kelime defterlerine kaydedilmesi diyerek görüşünü bildirmektedir. Kitaptaki etkinlikler haricinde kelime öğretimi için teknolojik cihazlardan faydalanan öğretmenlerden Ö4'ün açıklaması şu şekildedir: daha çok akıllı tahtadan faydalanıyorum, resimleri gösterip günlük hayatla ilişkilendirmelerini sağlamaya çalışıyorum.

Tablo 9.

Metin İşleme Süreçlerinde Kelime Öğretimi Yöntemlerine İlişkin Bulgular

\begin{tabular}{ll}
\hline \multicolumn{2}{l}{ Metin işleme süreçlerini yürütme yöntemleri } \\
\hline Tahmin etme & (Ö1, Ö2, Ö4, Ö8, Ö11, Ö6, Ö14) \\
Bağlamdan hareket etme & (Ö3, Ö5, Ö7, Ö9, Ö10, Ö12) \\
Eğitici oyunlar & (Ö15) \\
Sözlüğe bakma & (Ö13) \\
\hline
\end{tabular}


Türkçe öğretmenlerine metin işleme sürecinde kelime öğretimini nasıl gerçekleştirdikleri sorulmuş ve bu yanıtlara göre hazırlanmış veriler Tablo 9'da gösterilmiştir. Bu süreçte öğretmenlerin çoğunun kelimenin anlamını tahmin ettirdiği, bazılarının bağlamdan hareketle kelime öğretimini gerçekleştirdikleri görülmektedir. Metin işleme sürecinde bilinmeyen kelime için doğrudan sözlüğe müracaat eden ve eğitsel oyunları tercih eden öğretmenlerin olduğu da görülmektedir. Metin işleme sürecinde tahmin etme yöntemini kullanan Ö6 düşüncesini, okumaya veya dinleme/izlemeye başlamadan anlamını bilmedikleri kelimeleri not etmelerini, kelimenin anlamını tahmin etmelerini istiyorum. Son olarak Türkçe sözlükten anlamını bulup cümle içinde kullanmalarını istiyorum şeklinde açıklamıştır. Kelime öğretim sürecini bağlamdan hareketle yürüten öğretmenlerden Ö12, fikrini şöyle dile getirmiştir: Bağlamdan hareket ediyoruz. Öncelik metni okuma, sonrasında kelimenin geçtiği cümleyi okuyup bağlamdan tahmin etme. En sonunda kelimenin anlamına sözlükten bakma ve kelimeyi cümle içinde kullanma. Metin işleme esnasında doğrudan sözlükten bakma yöntemini Ö13, metni okurken bilmedikleri kelime olursa daire içine almalarını, metin bittikten sonra sözlükten bakıp örnek cümlede kullanmalarını söylüyorum diyerek ifade ederken, Ö15 kelimenin anlamı doğrultusunda öğrencilerle eğitsel oyunlar oynama, kısa canlandırma yaptı̆̆ımız uygulamalar şeklinde görüş belirtmiştir.

Tablo 10.

Kelime Öğretimiyle İlgili Gelişmelerin, Yayınların Takip Edilme Durumlarına İlişkin Bulgular

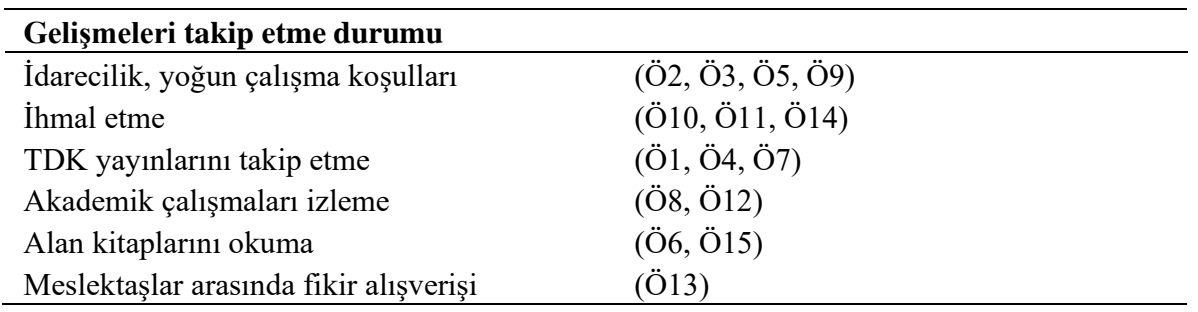

Türkçe öğretmenlerinin kelime öğretimi ile ilgili güncel gelişmeleri takip etme durumlarına ait veriler Tablo 10'da sıralanmıştır. Tablo 10'a göre öğretmenlerin çoğu kelime öğretimiyle ilgili gelişmeleri yoğun ders yüklerinden, MEB'in evrak prosedürlerinin fazla olmasından ve konuya ilgi duymadıklarından takip edememektedir. Öğretmenlik yaparken aynı zamanda yüksek lisans yapan öğretmenlerden bazıları makale ve tezleri takip ederken, Türk Dil Kurumu'nun yeni yayınlarını ve Türkçe alan kitaplarını takip eden öğretmenler de bulunmaktadır. Gelişmeleri takip edememe gerekçesini Ö3, okul işleriyle fazla yoğunum çünkü ögretmenliğin yanı sıra müdür yardımcılı̆̆ yapıyorum bu yüzden gerek yayınlardan gerek gelişmelerden haberdar olamıyorum şeklinde dile getirmiştir. Kelime öğretimi ile ilgili makale ve tezleri izleyen Ö11, ortaokula yönelik kelime ögretimi ile ilgili makaleleri takip ediyorum. Bu makaleler sayesinde kelime ögretimi ile ilgili 
çalışmalarda değinilen konular, kullanılan yöntemler ve bu konuda önerilerin neler olduğunu öğrendiğini ifade etmiştir. Güncel gelişmelerin takip edilmesi ile ilgili olarak Ö8, TDK sözlüklerinin son basımlarını takip ederek muallakta kalan kelimelerin yazımı ve anlamı konusunda öğrencilere rehberlik ettiğini ifade ederken, Ö15, Kamu Personeli Seçme Sınavına hazırlanırken almış olduğu alan kitaplarını incelediğini söylemiştir.

Tablo 11.

Kelime Ö̆̆retimi Süreçlerinde Karşılaşılan Sorunlara İlişkin Bulgular

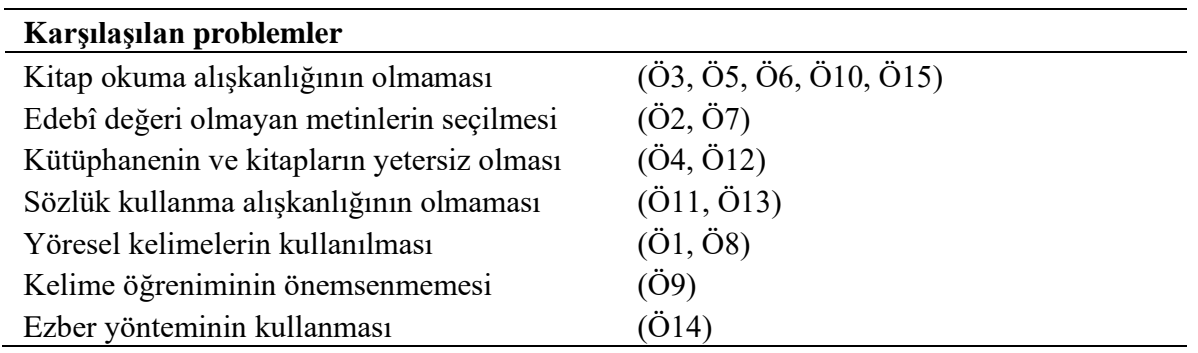

Tablo 11'de öğretmenlerin kelime öğretiminde karşılaştıkları problemlere yer verilmiştir. Öğrencilerin kitap okuma alışkanlıklarının olmaması, öğrenilen kelimelerden çok yörelerine özgü ifadeleri sık kullanmaları, ders kitaplarında edebî niteliği bulunmayan metinlerin bulunması ve öğrencilerin sözlük kullanma alışkanlıklarının olmaması, okuldaki kütüphane ve kitap imkânlarının yetersiz olması sorunlar arasında yer almaktadır. Okuma alışkanlığının olmamasını sorun olarak ifade eden Ö15'in düşüncesi karşılaştığım en büyük sorun öğrencilerin okuma alışkanlığının olmaması bu yüzden de kelime dağarcıklarının zayıf olması gelmektedir şeklindedir. Bu konudaki sorunu Ö8, çalıştı̆̆ım okulda ögrencilerin yöresel ă̆ız kullanmaları, basit kelimeleri bile anlamalarını, öğrenmelerini engellemektedir şeklinde ifade ederken, Ö2 sorunu, ders kitaplarına seçilen metinler edebî değeri olmayan, anlatımı zayıf, öğrencilerde okuma zevki oluşturamayan şiir, öykü, anı ve oyunların seçilmesi şeklinde dile getirmektedir. Öğretmeni sözlük olarak gören ögrencilerin sözlük kullanma alışkanlı̆̆ı edinememeleri (Ö11), okullarımızın çoğunda ögrencilerimize serbest okuma olanaklarının verilebileceği kitaplık, kütüphane gibi merkezler mevcut değil olanlar da yetersiz (Ö4), kelime öğreniminin öneminin ögrenciler tarafindan anlaşılmaması ve bu konuda öz disiplinlerini oluşturmamaları (Ö9) öğretmenlerin kelime öğretimi sırasında karşılaştıkları sorunlar arasında yer almaktadır. 
Tablo 12.

Öğretmenlerin Sorunlar için Önerilerine İlişkin Bulgular

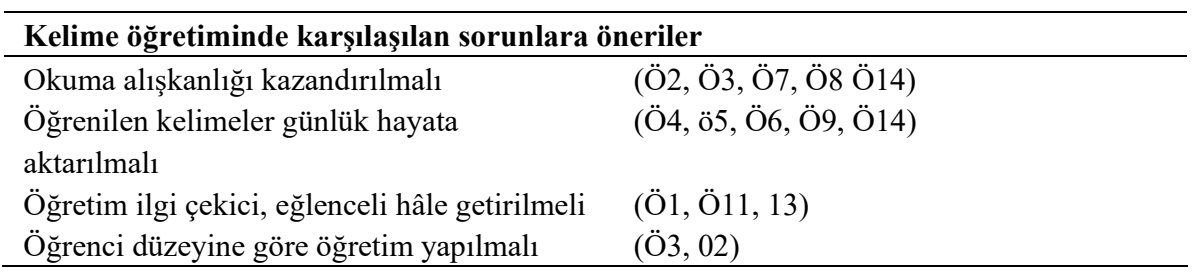

Tablo 12'de Türkçe öğretmenlerinin kelime öğretiminde karşılaştıkları sorunların çözümüne ilişkin çözüm önerilerine ilişkin veriler yer almaktadır. Tablo 12'ye göre ilk sıralarda öğrenilen kelimelerin günlük yaşam becerilerine dönüştürülmesi, günlük hayatta, konuşmalarında, yazılarında kullanmaları ve öğrencilerin okuma alışkanlıkları kazanmaları gerektiği yer almaktadır. Kelime öğretimi uygulama, etkinlik, yöntem ve tekniklerinin öğrencilerin ilgisini çekebileceği ve daha eğlenceli hazırlanması, Türkçe metinlerine alınacak metinlerde yer alan kelimelerin öğrencinin anlamakta zorlanacağı kelimelerden seçilmemesi diğer öneriler arasında yer almaktadır. Kelimelerin günlük hayata transfer edilmesi gerektiği görüşünde olan Ö6’ya göre öğrencilerin ögrendikleri kelimeleri bayram klyafeti düşünüp onu giymek yani sözcüğü günlük hayatta kullanmak için heyecan duymalarını sağlamak gerekmektedir. Ö7 de kelime öğretimi için önerilerini kitap okuma alışkanlı̆̆l kazandırllmalı, dili ve Türkçe dersini okul yaşamının da ötesinde günlük hayata taşınması sağlanmalıdır şeklinde aktarmıştır. Ders kitaplarına daha eğlenceli ve farklı etkinler konulması (Ö11), anlamını bilmekte öğretmenlerin bile zorlanacă̆ Arapça ve Farsça kelimeler yerine Türkçe kelimelerin öğretilmesi, etkinliklerdeki kelimelerin ögrenci seviyesine göre hazırlanması da (Ö3) kelime öğretimi için öğretmen önerileri arasında bulunmaktadır.

\section{Tartışma ve Sonuç}

Görüş bildiren Türkçe öğretmenlerinin üniversite eğitimlerinde kelime öğretimi konusunda yeterince bilgi edinemedikleri görülmektedir. Yağc1, Katranc1, Erdoğan ve Uygun (2012) sınıf öğretmenlerinin lisans eğitimlerinde öğrenmeleri gereken bazı yöntem ve teknikler hakkında yeterince bilgilendirilmediklerini, öğretmenlerin kelime öğretimini bireysel çabalarıyla öğrendiklerini ifade etmiştir. Çalışma bu yönüyle daha önce yapılan çalışmayla benzerlik göstermektedir.

Kılavuz kitaplarının kaldırılmasının kelime öğretimi üzerine etkisine bakıldığında bazı öğretmenler kılavuz kitapların kaldırılmasını olumsuz karşılarken bazı öğretmenler uygulamayı olumlu bulmaktadır. Öğretmenlerden bazılarına göre, değişiklik kelime öğretimini herhangi bir şeklide etkilemezken, bazılarına göre durum öğretmenin deneyimine göre değişebilmektedir. 
Ders ve çalışma kitaplarının birleştirilmesi kelime öğretimi bağlamında olumlu karşılanmaktadır. Söz konusu değişikliğin olumsuz olduğunu ve herhangi bir etkisinin bulunmadığını düşünen öğretmenler de mevcuttur.

Türkçe öğretmenlerine göre ders kitaplarındaki kelime öğretimi etkinlikleri Türkçe Öğretim Programıyla uyumludur. Söz konusu etkinliklerin bir kısmının uyum gösterirken bazılarının uyum göstermediği bazılarının da kısmen uyumlu olduğu düşünülmektedir. Mert (2013) Türkçe öğretim programındaki kazanımlarla etkinliklerin uyumlu olmadığını, çalışma kitaplarındaki kelime öğretimi etkinliklerinin sistemli bir şekilde hazırlanmadığını ifade etmiştir. Çalışma bu sonucu ile başka çalışmalar ile benzer özellik göstermektedir.

Türkçe ders kitaplarındaki kelime öğretimi etkinliklerin yeterli olma durumu incelendiğinde, etkinliklerin yeterli olduğunu düşünen öğretmenlerle yetersiz olduğunu düşünen öğretmenlerin eşit oldukları, bazı öğretmenlerin durumu kısmen yeterli kabul ettikleri görülmektedir. Mert'in (2013) çalışmasında tespit ettiği Türkçe çalışma kitaplarında yer alan sözcük öğretimine yönelik etkinliklerin yeterli miktarda olmadığı sonucu, çalışma ile benzerlik göstermektedir.

Türkçe öğretmenlerinin, kelime öğretimi için farklı süreler ayırdıkları görülmektedir. Bazı öğretmenler kelime öğretimi için 15, 20 ve 80 dakika gibi farklı süreler ayırabilirken durum bazen sınıf düzeyine göre değişmektedir.

Türkçe ders kitaplarındaki etkinlikler haricinde öğretmenler tarafından yapılan uygulamalar/etkinlikler arasında en çok kelime oyunlarının tercih edildiği, onu sırasıyla kitap okuma, kelime defteri tutma, yazma çalışmaları, teknolojiden yararlanma ve beyin firtınası takip ettiği görülmektedir. Yılmaz ve Doğan (2014) da çalışmalarında öğretmenler, ders kitaplarındaki etkinliklere ek olarak bazı bireysel çalışmalar yaptıklarını tespit etmiştir. Ulaşılan sonucun bu çalışmanın sonuçları ile benzerlik gösterdiğini söylemek mümkündür.

Türkçe öğretmenlerinin metin işleme süreçlerinde daha çok tahmin ettirme yöntemini kullandıkları, bazı öğretmenlerin bağlamdan giderek, bazılarının direkt sözlüğe bakarak süreçleri yürüttükleri görülmektedir.

Öğretmenlerin kelime öğretimi ile ilgili güncel gelişmeleri takip etme durumları incelendiğinde öğretmenlerin büyük çoğunluğu ders yükü fazlalığı ve idari görevlerinden dolayı gelişmeleri takip edememektedir. Çalışmaya katılan öğretmenlerden bazıları kelime öğretimi ile ilgili tez ve makaleleri incelerken bazı öğretmenler de TDK'nin güncel yayınlarını ve lisans dönemlerinde aldıkları kaynakları takip etmektedir.

Öğretmenlerin kelime öğretiminde karşılaştıkları sorunların başında öğrencilerin okuma alışkanlığı edinmemeleri gelmektedir. Öğrencilerin yöresel ifadeleri tercih etmeleri, sözlük alışkanlıklarının olmaması, okullardaki kütüphanelerin yeterli 
olmaması, kelime öğretiminin gereği kadar önemsenmemesi karşılaşılan sorunlar arasında yer almaktadır.

Kelime öğretiminde karşılaşılan sorunları dile getiren Türkçe öğretmenlerinin kelime öğretimi sürecinde yaşadıkları sorunlara çözüm önerilerine bakıldığında öğrenilen kelimelerin günlük hayata aktarılması, okuma alışkanlığı kazandırılması, öğretimin ilgi çekici, eğlenceli hâle getirilmesi, metinlere alınacak kelimelerin öğrenci düzeyine göre olması gerektiği şeklinde çözüm önerileri sundukları görülmektedir. Göçer (2010) ders kitaplarına seçilecek metinlerin kelime kadrosuna dikkat edilmesi ve metinlerin seçiminde sınıf düzeyi, öğrenci özellikleri, mevcut kelime dağarcığı gibi durumların ihmal edilmemesi gerektiğini ifade etmektedir.

Sonuç olarak, Türkçe öğretmenlerinin eğitimleri sırasında kelime öğretimi konusunda gereğince bilgi edinemedikleri görülmektedir. Ders kitapları ile çalışma kitaplarının birleştirilmesinin kelime öğretimini olumlu; kılavuz kitaplarının kaldırılmasının olumsuz etkilediği görülmektedir. Ders kitaplarında yer alan kelime öğretimi etkinliklerin programla uyumlu, etkinlik miktarının kısmen yeterli olduğu tespit edilmiştir. Kelime öğretimine ayrılan sürelerin farklı olduğu ve sınıf düzeylerine göre değiştiği, öğretmenlerin, kitaplardaki etkinlikler dışında kelime oyunları, okuma ve yazma etkinlikleri, kelime defteri tutma uygulamaları yaptırdıkları görülmektedir. Öğretmenlerin metin işleme süreçlerinde tahmin ettirme, bağlamdan anlamı buldurma gibi yöntemler kullandıkları, kelime öğretimiyle ilgili yayınları ve gelişmeleri genellikle takip edemedikleri görülmektedir. Türkçe öğretmenleri, öğrencilerin kitap okuma ve sözlük kullanma alışkanlıklarının olmamasını kelime öğretimi sürecinde problem olarak görmektedirler.

\section{Öneriler}

Çalışmada elde edilen bulgulardan hareketle aşağıdaki önerileri sıralamak mümkündür:

- $\quad$ ürkçe Eğitimi Ana Bilim Dalı programında kelime öğretimiyle ilgili dersler ve uygulamalar artırılabilir.

- Öğrencilere edindikleri kelimeleri kullanabilecekleri eğitim ortamları sağlanabilir.

- Okullarda sözlük okuma etkinlikleri düzenlenebilir.

- Öğretmenlerin kelime öğretimiyle ilgili çalışmaları takip etmeleri desteklenebilir, öğretmenler teşvik edilebilir.

\section{Çıkar Çatışması ve Etik Bildirimi}

Yazarlar, aralarında çıkar çatışması bulunmadığını ve tüm araştırmacıların çalışmaya katkı sunduğunu beyan etmiştir. Yazarlar, tüm etik kurallara uyduklarını bildirmiştir. 


\section{Kaynakça}

Açıkgöz, B. (2008). İlköğretim 6. sınıf Türkçe kitaplarının kelime serveti bakımından değerlendirilmesi (Tez No. 220072) [Yüksek lisans tezi, Afyon Kocatepe ÜniversitesiAfyon]. Yükseköğretim Kurulu Başkanlığı Tez Merkezi.

Akar, A. (2019). Düşünen Türkçe. Ötüken Neşriyat.

Aksan, D. (2014). Anadilimizin söz denizinde (3. Basım). Bilgi Yayınevi.

Alkış Küçükaydın, M., \& İşcan, A. (2017). İlköğretim 3.sınıf Türkçe ders kitapları ve öğretmen kılavuz kitabının yapılandırmacı öğrenme yaklaşımına uygunluk düzeyi. Ana Dili Eğitimi Dergisi, 5(1), 1-13. https://doi.org/10.16916/aded.268692

Anagün, Ş. S. (2008). İlköğretim beşinci sınıf öğrencilerinde yapılandırmacı öğrenme yoluyla fen okuryazarlı̆̆ının geliştirilmesi: bir eylem araştırması (Tez No. 229235) [Doktora tezi, Anadolu Üniversitesi-Eskişehir]. Yükseköğretim Kurulu Başkanlığı Tez Merkezi.

Anılan, H., \& Genç, B. (2011). Türkçe dersinde öğrenilen yeni sözcüklerin yazılı anlatımlarda kullanım durumu. Ahi Evran Üniversitesi Kırşehir Eğitim Fakültesi Dergisi, 12(1), 111132.

Arı, G. (2003). Illköğretim altıncı sınıf Türkçe ders kitaplarındaki kelimeler ve bu kelimelerin kullanılabilirliği (Tez No. 130333) [Yüksek lisans tezi, Marmara Üniversitesi-İstanbul]. Yükseköğretim Kurulu Başkanlığı Tez Merkezi.

Aru Akyüz, S. (2013). İlköğretim programına göre hazırlanan Türkçe ders kitaplarında kelime hazinesini geliştirmeye yönelik planlamanın incelenmesi (Tez No. 336106) [Yüksek lisans tezi, Gazi Üniversitesi-Ankara]. Yükseköğretim Kurulu Başkanlığı Tez Merkezi.

Baskin, S., Iscan, A., Karagöz, B., \& Birol, G. (2017). The use of vocabulary learning strategies in teaching Turkish as a second language. Journal of education and practice, 8(9), 126-134.

Baş, B., \& Demirci, S. (2015). 2. sınıf Türkçe ders kitabındaki metinlerle çalışma kitaplarındaki etkinliklerin söz varlığı açısından karşılaştırılması. Ana Dili Eğitimi Dergisi, 3(1), 17-29. http://dx.doi.org/10.16916/aded.22794

Bay, Y. (2014). ABD'nin anasınıfı ve ilköğretim birinci sınıf okuma kitaplarının kelime öğretimi açısından incelenmesi. Turkish Studies, 9(12), 17-30. http://dx.doi.org/10.7827/TurkishStudies.7452

Baysal, A. D. (2007). İlköğretim 7. sınıf Türkçe ders kitaplarınının kelime serveti bakımından değerlendirilmesi (Tez No. 206184) [Yüksek lisans tezi, Afyon Kocatepe ÜniversitesiAfyon]. Yükseköğretim Kurulu Başkanlığı Tez Merkezi.

Çiftçi, Ö., \& Çeçen, M. A. (2010). İlköğretim 6-8. sınıf Türkçe ders kitaplarındaki metinlerin anlamı bilinmeyen sözcükler açısından değerlendirilmesi. Türkçe ögretiminde güncel tartışmalar içinde (s. 122-136). Ankara Üniversitesi TÖMER Yayınevi. 
Demir, C. (2010). İlköğretim 2. kademe Türkçe ders kitaplarının içerik ve sözcük sayısı bakımından değerlendirilmesi. Türkçe öğretiminde güncel tartışmalar içinde (s. 53-66). Ankara Üniversitesi TÖMER Yayınevi.

Ergin, M. (1986). Türk dil bilgisi. Boğaziçi Yayınları.

Göçer, A. (2007). Türkçenin yabancı dil olarak öğretiminde kullanılan ders kitaplarının ölçme ve değerlendirme açısından incelenmesi. Dil Dergisi, 137, 30-46. http://dx.doi.org/10.1501/Dilder_0000000078

Göçer, A. (2010). Türkçe eğitiminde öğrencilerin söz varlığını geliştirme etkinlikleri ve sözlük $\begin{array}{lll}\text { kullanımı. Turkish } & \text { Studies, 5(1), }\end{array}$ http://dx.doi.org/10.7827/TurkishStudies.1318

Göçer, A. (2015). Türkçe dersi metin işleme sürecinde bağlam temelli sözcük öğretimi ve etkin sözcük dağarcığı oluşturmadaki işlevi. Ana Dili Eğitimi Dergisi, 3(1), 48-63. http://dx.doi.org/10.16916/aded.39222

Göçer, A. (2018). Türkçe öğrenme ve öğretim yaklaşımları-metin işleme süreçli-mikro öğretim uygulama örnekli (3. Bask1). Pegem Akademi Yayınları.

Gündoğdu, E. A. (2012). İlköğretim altıncı sınıf Türkçe dersi sözcük öğretimi etkinliklerinin çeşitli değişkenler açısından incelenmesi. Uluslararası Türkçe Edebiyat Kültür Eğitim Dergisi, 1(1), 201-217. https://doi.org/10.7884/teke.18

Güneş, F. (2013). Kelimelerin gücü ve zihinsel sözlük. Siirt Üniversitesi Sosyal Bilimler Enstitüsü Dergisi, 1, 1-24.

Güzel, G. (2015). Ortaokul Türkçe ders kitaplarında sözcük öğretiminin yaratıcı dil öğretimi açısından değerlendirilmesi (Tez No. 463402) [Yüksek lisans tezi, Başkent ÜniversitesiAnkara]. Yükseköğretim Kurulu Başkanlığı Tez Merkezi.

Kaya, E. (2008). İlköğretim 2. kademe Türkçe ders kitaplarında sözvarlı̆̆ı incelemesi [Yayımlanmamış yüksek lisans tezi]. Pamukkale Üniversitesi.

Kurudayığlu, M., \& Karadağ, Ö. (2006). Ortak kelime hazinesi kazandırmada ilköğretim sekizinci sınıf Türkçe ders kitaplarının durumu. Ahi Evran Üniversitesi Kırşehir Eğitim Fakültesi Dergisi, 7(2), 353-343.

MEB (2018). Türkçe dersi öğretim programı (İlkokul ve Ortaokul 1, 2, 3, 4, 5, 6, 7 ve 8. Siniflar).

http://mufredat.meb.gov.tr/Dosyalar/201812312239736T\%C3\%BCrk\%C3\%A7e\%20\%C3 \%96\%C4\%9Fretim\%20Program\%C4\%B1\%202018.pdf (Erişim Tarihi:25.12.2018).

Mert, E. L. (2010). İlköğretim Türkçe ders ve çalışma kitaplarında kullanılan atasözü ve deyimlere yönelik bir sözvarlığı çalışması. Türkçe öğretiminde güncel tartışmalar içinde (s. 113-12). Ankara Üniversitesi TÖMER Yayınevi. 
Mert, E. L. (2013). İlköğretim Türkçe programı ile Türkçe çalışma kitaplarındaki kazanım ve etkinliklerin sözcük öğretimi açısından değerlendirilmesi. Dil ve Edebiyat Eğitimi Dergisi, 2(5), 13-31.

Miles, M. B. \& Huberman, M. A. (1994). Qualitative data analysis. Sage Publication.

Nation, P., \& Newton, J. (1997). 19 teaching vocabulary. Second language vocabulary acquisition: A rationale for pedagogy, 238.

Özaslan, A. (2006). Kelime oyunları ile kelime dă̆arcığııın gelişstirilmesinin okuduğunu anlama düzeyine etkisi (Tez No. 189306) [Doktora tezi, Selçuk Üniversitesi-Konya]. Yükseköğretim Kurulu Başkanlığı Tez Merkezi.

Yağc1, E., Katranc1, M., Erdoğan, Ö., \& Uygun, M. (2012). Sınıf öğretmenlerinin kelime ögretiminde karşılaştıkları sorunlar ve kullandıkları yöntem-teknikler. Uluslararası Eğitim Programları ve Öğretim Çalışmaları Dergisi, 2(4), 1-12.

Yıldırım, A., \& Şimşek, H. (2016). Sosyal bilimlerde nitel araştırma yöntemleri (10. Baskı). Seçkin Yayıncılık.

Yılmaz, T., \& Doğan, Y. (2014). 7. sınıf öğrencilerinin anlamını bilmedikleri kelimeler ve Türkçe ders kitaplarındaki kelime çalışmaları bağlamında kelime öğretimi. Mustafa Kemal Üniversitesi Sosyal Bilimler Enstitüsü Dergisi, 11(25), 279-295.

\section{Extended Abstract}

Words have an important function in daily life, in communication, in understanding what we listen, watch, read, and express our feelings, thoughts and wishes. A people who is a social being develops the skills of understanding and telling through words, one of the important elements of language.

It is known that vocabulary in various national and international examinations affects the level of comprehension, interpretation and thus academic achievement. Educators acknow the relationship between vocabulary and academic achievement, and think that vocabulary studies are an important part of native language education because lack of vocabulary limits academic achievement (Özaslan, 2006, p. 35). Although word teaching is carried out within the scope of all courses, the biggest responsibility in this area falls on the courses where native language teaching is performed (Asli \& Genç, 2011, p. 113). Improving students' language proficiency and enriching their vocabulary are included in the applications of Turkish lesson. In this regard, it is necessary to make vocabulary development activities aimed and planned in schools especially in Turkish lessons (Göçer, 2015, p. 18). At the beginning of the resources used in the implementation of word teaching are textbooks. Activities in textbooks, methods and techniques of application of activities are among the important elements of vocabulary teaching processes. 
It is seen that many studies about Turkish courses and workbooks and teacher guide book are done and that the studies are centered around the subjects such as word frequency, word teaching methods and techniques, and the harmony between the courses and workbooks. With the change in the 2018-2019 academic period, teacher guide books have been removed and textbook and student work books have been merged. This study was based on the question nasil How did the abolition of Turkish teacher's guide books and the combination of Turkish textbooks and workbooks affected word teaching?" The abolition of teacher guide books and the lack of studies on the effect of combining Turkish workbooks with Turkish textbooks on vocabulary teaching were effective in shaping this study. In this respect, the study is expected to contribute to the field.

Qualitative research method was used in this study in descriptive model. Qualitative research is a type of research that reveals facts and events in a realistic and holistic manner using data collection methods such as observation, interview and document analysis (Yıldırım \& Şimşek, 2008). Participants in this study were determined according to easily accessible state sampling from qualitative research sampling types. In this study, the researcher created the Working Group from the Turkish teachers with whom he was in contact with and used easily accessible situation sampling in order to speed up the research and provide practicality. Interview as a data collection tool was preferred in the study. In order to master the data obtained by the interview form, the written texts were read several times at different times and in the process, themes, categories and codes were made in parallel with the interview questions of the research.

It is observed that the majority of Turkish lesson teachers who participated in the study did not receive sufficient academic information about word teaching during their university education and that few of the teachers were informed about word teaching. When we look at the effect of the removal of teacher guide books on word teaching, some teachers find the removal of guidebooks negative, while some teachers find the application positive. When the effect of combining study and textbooks on vocabulary teaching is examined, the change made by the majority of teachers is considered to be positive. According to the opinions regarding the compatibility of the word teaching activities in textbooks with the Turkish Teaching Program, the program is compatible with the activities.

As a result, Turkish teachers do not have enough academic knowledge on word teaching, abolishing teacher guide books adversely affects vocabulary teaching, combining textbooks and workbooks positively affects vocabulary teaching and it is seen that the vocabulary teaching activities in Turkish textbooks are compatible with the Turkish curriculum. Vocabulary teaching in renewed Turkish lesson books in activities is partly sufficient, in Turkish lessons, the time allocated for vocabulary teaching varies according to teacher and grade levels, teachers, word games, reading and writing activities, word book keeping, etc. they have various applications. It is 
seen that teachers use methods such as prediction, acting from context, and generally do not follow publications and developments related to vocabulary teaching. It was found that Turkish lesson' teachers perceived the lack of habits of students reading books and using dictionary as a problem in vocabulary teaching process. 